\title{
THE COLUMN OF CLEOPATRA III AND PTOLEMY IX FROM KOM OMBO IN THE GEM (45481)
}

\author{
Ali Abdelhalim ALI \\ Faculty of Arts, Ain-Shams University \\ ali.abdelhalim@art.asu.edu.eg
}

\section{ABSTRACT}

This is the publication of a column currently in the Grand Egyptian Museum at Giza. This column is covered with scenes, hieroglyphic texts, and decorative motifs. It is one of the few depictions of a Ptolemaic queen, Cleopatra III, alone offering to deities. Its content shows a period of coregency between her and her son Ptolemy IX. Moreover, it bears new motifs, such as the frieze of Hathoric faces and the rekhytbird adoring the divine children of Kom Ombo.

This research presents a theological, historical, and palaeographical analytical study of the scenes and texts of the column. Indeed, it also shows the two divine children of Kom Ombo receiving offerings from Ptolemy IX and his mother. A reconstruction of the column is suggested, either as a complete element or locating it on the plan of the Mammisi of Kom Ombo.

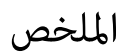

البحث الحالي عبارة عن نشر ودراسة لعمود من كوم امبو وهو محفوظ حاليًا بالمتحف المصري المدي الكبير في

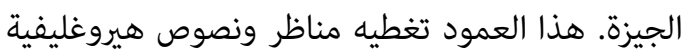
فضلًا عن عناصر زخرفية. كما أنه يمثل أحد الحد الحالات النادرة التي تظهر فيها ملكة بطلمية (كليوباترا الثالثة هنا) منفردة تقدم القرابين للآلهة. كما أن لها لها أهمية

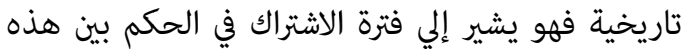

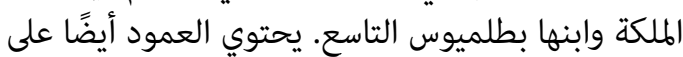
عناصر زخرفية مميزة تتمثل في أعلى العمود في إفريز

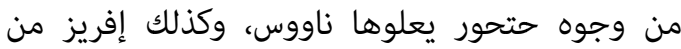

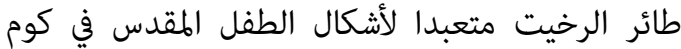

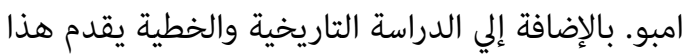

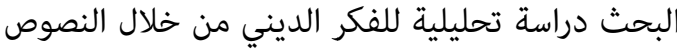

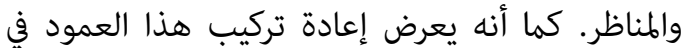

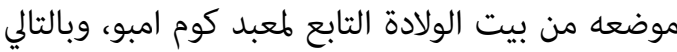

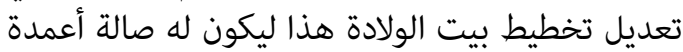

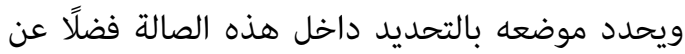
تحديد ارتفاعه وما كان يحتويه من عناصر معمارية.

\section{KEYWORDS}

JE 45072; rekhyt-bird; Hathor face; coregency; Mammisi; Khonsu-Horus; Panebtaui-Pa-Khered; Myrrh; Milk; Lunar deities; Divine kingship; Palaeography.

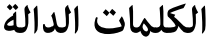

رخيت، وجه حتحور، اشتراك في الحكم، بيت ولادة، تاج

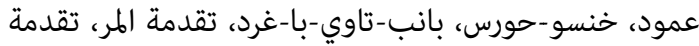
اللبن، القمر، الملكية المقدسة، باليوجرافي، تخطيط معماري. 


\section{INTRODUCTION AND BACKGROUND}

The column under study is now stored in the laboratory of the GEM to be exhibited in its future collection. It was uncovered in the sebakhs at Kom Ombo temple as mentioned by de Morgan. ${ }^{1}$ In 1914, it was registered in the Egyptian Cairo Museum at Tahrir under JE 45072 and SR/10516 (Fig. 1a). In 2018, it was moved to the Grand Egyptian Museum, accessing a new number GEM 45481 (Fig. 1b).

Old photos (between 1893 and 1914) show the pieces of this column being gathered after its discovery in situ (Fig. 2a). De Morgan copied the texts and the vignettes of the main scenes. However, he neglected the lower and upper parts of this column despite their importance. In addition, his copy (Fig. 2b) includes several epigraphic errors and hieroglyphic signs are missing. The current study produces therefore a fresh photogrammetry and an accurate line drawing of the inscriptions on this column (Fig. 3a-b). Such reproduction will help correcting the epigraphic errors of de Morgan and complete the missing parts. An exact description and a complete detailed analysis are then based on this new reproduction.

\section{DESCRIPTION (Fig. 3a-b)}

Total height of the current state: $217 \mathrm{~cm}$. Diameter: lower $157 \mathrm{~cm}$, upper $144.5 \mathrm{~cm}$. Weight: $650 \mathrm{Kg}$. Material: red sandstone from Gebel Es-Silsileh.

The column, in its current state, is composed of five cylinder-shaped blocks. It is decorated in low relief with various inscribed scenes, texts, and decorative motifs. Those inscriptions are arranged upwards in five sections (Fig. 3b): section a (rekhytbirds adoring divine children), section $\mathrm{b}$ (bandeau-text), section c (Ptolemy IX and Cleopatra III offering to the divinities in the two main scenes), section d (recurring decoration of Hathor faces with naoi), and section e (bundled papyrus reeds). Each section is separated from the other by horizontal lines.

Section a contains four rekhyt-birds on baskets while adoring four divine children. Each child god is depicted seated upon a papyrus flower, putting a finger towards their mouth, and holding the flail in the other hand. Two of these divine children (nos. 4 and 8 in the line drawing) wear the feather crown of Amun and look rightward, while the third (no. 6) wears the solar disk on its head, and the fourth (no. 2) the lunar disk. These two latter look leftward. The child god on the most right (no. 4) has exceptionally the side hair lock. The most left child god (no. 8) is called PanebtauiPa-Khered, while the right one is Nefer-Hor. The names of the two deities in the middle are lost. Beneath the divinities and the baskets, there are papyri emerging from other floral decors of stipules.

Short hieroglyphic texts are inscribed in small columns between the divinities and the rekhyt-birds. These texts are rough and damaged, but the texts translate as follows,

\footnotetext{
* I would like to thank my colleagues at the Tahrir Museum and at the Grand Egyptian Museum.

${ }^{1}$ de Morgan et. al. Kom Ombos, KO 1063-1064 341. PM VI, 201 mentions this column beside other objects as Miscellaneous 'from the temple area, but exact provenance is unknown'.
} 
from the centre outwards: ${ }^{1}$

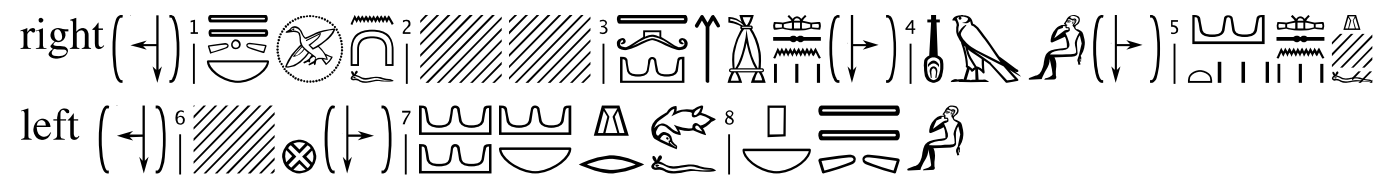

\begin{tabular}{|l|l|l|}
\hline Line & Transliteration & Translation \\
\hline 1 & $t 3 w y$ nbw sd3d3 $n$ hrryt.f & All lands ${ }^{2}$ tremble because of terror of him \\
\hline 2 & {$[\ldots \ldots]$} & {$[\ldots \ldots]$} \\
\hline 3 & $t 3-s t y \underline{d} b 3 w w$ m g3wt.sn & Nubian are equipped with their bundles \\
\hline 4 & $n f r-h \underline{r}$ & Nefer-Hor \\
\hline 5 & $h 3 s w t \underline{d} b 3 w . s n \underline{h} r[t b w] . f$ & $\begin{array}{l}\text { The foreign lands and their gifts are beneath his } \\
{[\text { soles }]}\end{array}$ \\
\hline 6 & {$[\ldots \ldots]$} & {$[\ldots \ldots]$} \\
\hline 7 & $h 3 s w t n b w \underline{h} r$ snd.f & All foreign lands are in fear of him. \\
\hline 8 & $p 3-n b-t 3 w y-(p 3)-\underline{h r d}$ & Panebtaui-(Pa)-Khered. \\
\hline
\end{tabular}

Section b represents the bandeau-text, which contains the titulary of both Ptolemy IX and his mother Cleopatra III. This bandeau-text runs in two symmetric directions, each beginning with the ' $n h$-sign. Three cartouches are written through this bandeautext, the coronation name of Ptolemy IX on the right side followed by the phrases 'Philometor, beloved from Tasenetneferet'. The cartouche of Cleopatra III lies on the left side, followed by the birth name of Ptolemy IX. ${ }^{3}$ This left part ends with the phrases 'Philometor, beloved from Panebtaui-Pa-Khered'.

Bandeau-text right:

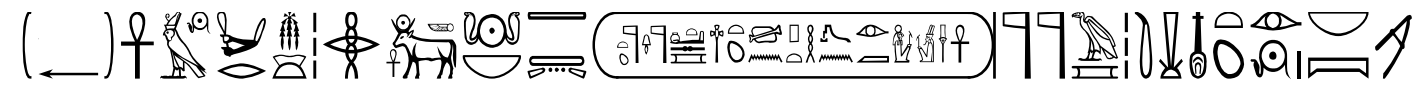

Bendeau-text left:

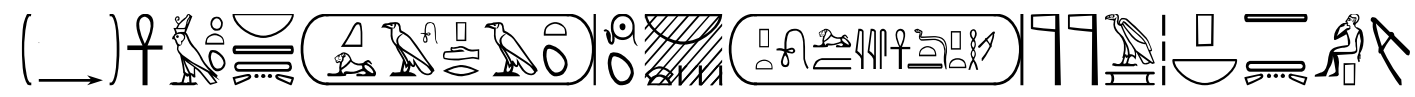

\begin{tabular}{|c|c|c|}
\hline side & Transliteration & Translation \\
\hline Right & 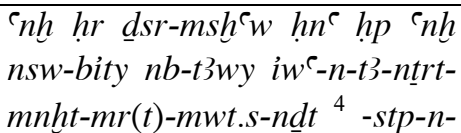 & $\begin{array}{l}\text { May Horus live, magnificent of appearance } \\
\text { together with the living Apis, king of Upper and }\end{array}$ \\
\hline
\end{tabular}

\footnotetext{
${ }^{1}$ Such reading is based on the orientation of the signs and according to the ${ }^{C} n h$-sign in the above bandeau-text, which is symmetric in all cases of bandeau-texts on columns, Abdelhalim, BandeauTexts, 287-304.

${ }^{2}$ Translating the apparent dual $t 3 w y-n b$ was plural 'all lands' after Quack, Incense, 47f. n. 45.

${ }^{3}$ De Morgan inverted the two halves of this bandeau-text, as he puts the right part below the scene of Ptolemy IX and vice versa. The hieroglyphic signs in the bandeau-texts belong to the king including his titulary and his epithets. Therefore, the ${ }^{\top} n h$-sign is always located below the two marginal columns of the deities. Details in Abdelhalim the Bandeau-Texts, 287-304.

${ }^{4}$ Instead, von Beckerath (Königsnamen, 242f) reads and transcribes the titular of Ptolemy IX as: $i w^{e}$ -

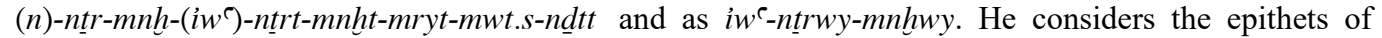
Ptolemy IX as the heir of his father Ptolemy VIII (Euergetes II $n t r-m n h$ ) and his mother Cleopatra III
}

- 3 - The Column of Cleopatra III and Ptolemy IX 


\begin{tabular}{|c|c|c|}
\hline & 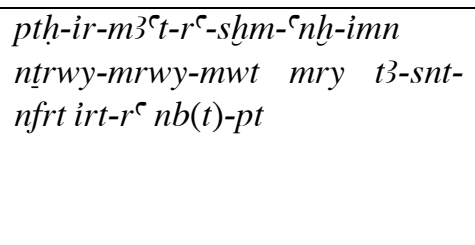 & $\begin{array}{l}\text { Lower Egypt, lord of the Two Lands: Heir of } \\
\text { Evergetis Philometor Soteira, the chosen of Ptah, } \\
\text { who performs Maat of Re, the living image of } \\
\text { Amun, Philometor, beloved from Tasenetneferet } \\
\text { the eye of Re, lady of the sky }{ }^{(1)} \text {. }\end{array}$ \\
\hline left & 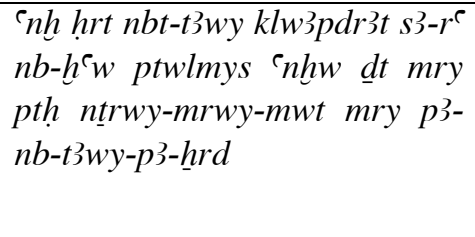 & $\begin{array}{l}\text { May the female Horus live, the lady of the Two } \\
\text { lands: Cleopatra (III), <and > son of Re, Lord of } \\
\text { the crowns: Ptolemy (IX) who lives eternally, } \\
\text { beloved from Ptah, Philometor, beloved from } \\
\text { Panebtaui-Pa-Khered }{ }^{(2)} \text {. }\end{array}$ \\
\hline
\end{tabular}

Section c (Fig. 3a-b) contains the two main scenes that occupy the biggest space in the middle of the column. The vignette on the right side (KO 1063) depicts Cleopatra III offering myrrh to Khonsu, while the left vignette (KO 1064) depicts Ptolemy IX offering two milk-jars to Panebtaui-Pa-Khered. All figures are accompanied with hieroglyphic texts.

Right side (KO 1063): Cleopatra III is dressed with a long robe. She wears a double feathered crown with two horns and a sun-disk, as well as the Uraeus on her forehead. She offers the myrrh to Khonsu-Horus on her right, and adores him with her left hand. In front of her, Khonsu-Horus holds the $w 3 s$-sceptre in his left hand, and the ruling symbols ( $h k 3$ and $n h h)$ in his right. In addition to the detailed side lock, Khonsu wears a headdress with bands behind his neck and the Uraeus on his forehead. The lunar disk upon his head is distinguished by a big cobra emerging from its middle upon the crescent. Khonsu-Horus is also distinguished by wrinkles below his breasts.

Left side (KO 1064): Ptolemy IX wears the double crown, which is detailed with the cobra on his forehead and the bands behind the neck, and the kilt with the bull tail in addition to a long dress. He offers two milk jars to Panebtaui-Pa-Khered, who stands before him holding the $w 3 s$-sceptre in his right hand, and the $n h h$ in his left. The $h k 3-$ symbol is missing here. Like Khonsu-Horus, Panebtaui-Pa-Khered wears a headdress with bands and the cobra as well as the side lock (here without details). Upon the head of Panebtaui-Pa-Khered, there is the solar disk with a big cobra coiled. The text accompanying the main scene on the Right side (KO 1063) is:

(Euergetis ntrt-mnht). The same opinion exists in Kurth, Ptolemaois, in: $L \ddot{A}$ IV, col. 1195. In our case, the existence of the egg and the $t$-sign (both for feminine) before the $1^{\text {st }} n t r$-sign inside the cartouche leads to read $t 3$-ntrt in reference to Cleopatra III, who took the epithet $t 3$-ntrt-mnht. The egg reappears inside the cartouche of the main scene of the current column (sec. c left 3). For Cleopatra III as Euergetis, see Bevan, Ptolemaic Dynasty, 326.

${ }^{1}$ Instead, Haroeris in the copy of de Morgan KO 1063.

${ }^{2}$ De Morgan transcribes Sobek in KO 1064. 
Title of offering:

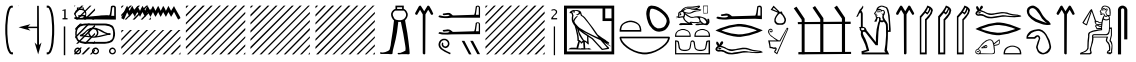

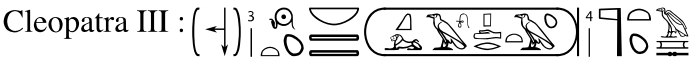

Marginal column behind Cleopatra III:

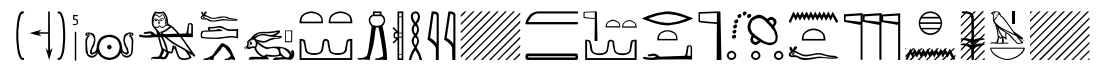

Khonsu-Horus:

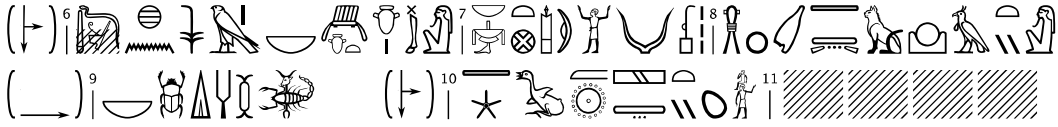

Marginal column behind Khonsu-Horus:

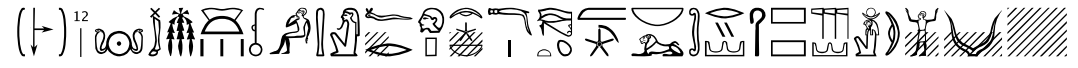

\begin{tabular}{|c|c|c|}
\hline Nr. & Transliteration & Translation \\
\hline & Title of the offering: & \\
\hline 1 & hnk ${ }^{\complement} n t w n$ [it.s...] ini $m^{`} w y[n w]$ & $\begin{array}{l}\text { Offering of the myrrh }{ }^{1} \text { to }[\text { her father ...] brought by } \\
\text { the hands [of] }\end{array}$ \\
\hline 2 & 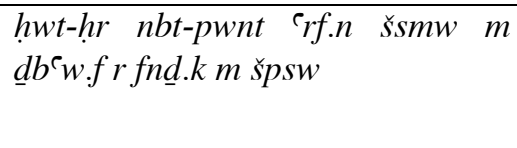 & $\begin{array}{l}\text { Hathor, lady of Punt, }{ }^{2} \text { which Shesemu pressed } \\
\text { through his fingers }{ }^{3} \text { to your nostrils }{ }^{4} \text { as costly } \\
\text { offerings }^{5}\end{array}$ \\
\hline & Śleqp'tr'TII: & \\
\hline 3 & $s 3 t-r^{\ulcorner} n b t-t 3 w y k l w 3 p d r 3 t$ & $\begin{array}{l}\text { Daughter of Re, Lady of the two lands Cleopatra } \\
\text { (III), }\end{array}$ \\
\hline 4 & ntrt-mryt-mwt.s & $\begin{array}{l}\text { The goddess, beloving of her mother (Thia- } \\
\text { Philometor) }{ }^{6}\end{array}$ \\
\hline & Marginal column of Cleopatra III: & \\
\hline 5 & $\begin{array}{l}n s w t-b i t t \quad m f d(t) \text { pwnt in hy } m \text { t3- } \\
n \underline{t} r \text { rdit idt-ntr } n \text { it-ntrw hnsw-hrr } \\
n b[3 w-i b]\end{array}$ & $\begin{array}{l}\text { Queen of Upper and Lower Egypt, who hastens } \\
\text { through Punt (to) bring the plants from the god's } \\
\text { land, who places the god's sweet to the gods }\end{array}$ \\
\hline
\end{tabular}

${ }^{1}$ The usual title is $\check{r}_{m s-}{ }^{-} n t w$ e.g. Edfou VII, 106, 6-8; VIII, 135, 7. Other titles are also known such as rdit-'ntw hr ht 'putting the myrrh on fire' e.g. Edfou VII, 59, 13; VIII, 57, 5 and $k 3 p$-' $n t w$ in Edfou VII, 324,14 . hnk-'ntw 'offering of myrrh' is attested either alone like in our case, or together with the offering of ointment in Edfou VIII, 60, 13.

2 'Lady of Punt' is a familiar title of Hathor but also of other goddesses like Isis and Mut. See Leitz, $L G G$ IV, 52-53. Cf. the same context (Hathor as lady of Punt) in the offering of myrrh in Edfou VIII, 140, 10-11.

${ }^{3}$ Cf. Edfou VII, 105, 17-106, 4. This phrase 'which Shesemu pressed through his fingers' occurs in the offering of ointment for instance (hnk-mdt) in the Opet temple at Karnak (Opet nr. 65).

${ }^{4} \mathrm{Cf}$. a similar phrase in an offering of myrrh Edfou VII, 130, 14-18. In Edfou VIII 52, 11 (w3hi $n$ fnd.. ).

${ }^{5}$ For this translation of šsw as 'costly offering' see Wb IV, 450.16-451.6; Wilson, Ptolemaic Lexicon, 1002.

${ }^{6}$ Von Beckerath., Königsnamen, 240f mentions the epithet of Cleopatra III as 'Thea Philadelphos', Egyptian: $t 3$-ntrt mryt sn.s. After the death of Ptolemy VIII, it seems that she changed this epithet into 'Thea Philometor'. Similar change is mentioned by Pestman, Textes démotiques, 66, 68, n. f, but from Euergetes to Philometor Soteira (see below). Thea Philometor Soteira is wrongly referred to as the cult name of Cleopatra II not III in Thissen, Kleopatra, in: $L \ddot{A}$ III, col. 453.

- 5 - The Column of Cleopatra III and Ptolemy IX 


\begin{tabular}{|c|c|c|}
\hline & & father, Khonsu-Horus lord of [joy]. \\
\hline & Khonsu-Horus: & \\
\hline 6 & $\begin{array}{l}\text { dd-mdw in hnsw-hr nb } 3 w t-i b \text { ib } \\
\text { whmm }\end{array}$ & $\begin{array}{l}\text { Recitation by Khonsu-Horus, lord of joy, the heart, } \\
\text { the tongue (lit. repeater), }{ }^{1}\end{array}$ \\
\hline 7 & nb nbyt iwn- $h^{\top \odot} w p-r n p w t$ & $\begin{array}{l}\text { lord of Kom Ombo, the jubilee pillar (moon), } \\
\text { opener of the years, }\end{array}$ \\
\hline 8 & sḥd-t3wy mi 3hty & illuminator of the two lands like Akhty, \\
\hline 9 & $n b \operatorname{hpr}(w) r d i \underline{t} 3 w^{(2)} n$ srk-ḥtyt & $\begin{array}{l}\text { lord of the forms (transformations), who gives the } \\
\text { wind/breath to the throat (who makes inhale), }\end{array}$ \\
\hline 10 & $s^{\top} n h \underline{t} \underline{t} 3 m-\underline{h} n w$ styt.f & he who perpetuates the male-child in his egg. \\
\hline \multirow[t]{2}{*}{11} & {$[\ldots \ldots]$} & {$[\ldots \ldots]$} \\
\hline & Marginal column of Khonsu-Horus: & \\
\hline 12 & 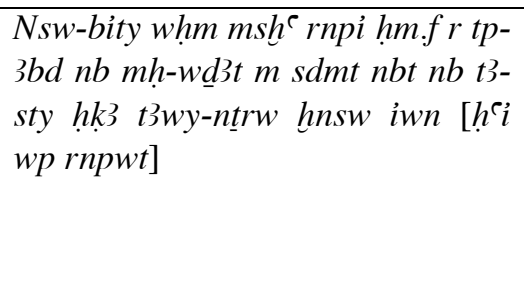 & $\begin{array}{l}\text { King of Upper and Lower Egypt, who repeats the } \\
\text { appearance, }{ }^{3} \text { his majesty becomes young at the } \\
\text { beginning of each month, who fills the } w d 3 t \text {-Eye in } \\
\text { every half-month-festival, as lord of Nubia, } \\
\text { sovereign of the lands of the gods, }{ }^{4} \text { Khonsu the } \\
\text { jubilee [pillar (moon), opener of the years]. }\end{array}$ \\
\hline
\end{tabular}

The text accompanying the main scene on the Left side (KO 1064) reads:

Title of the Offering:

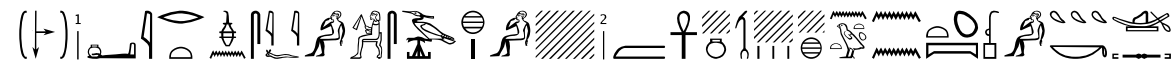

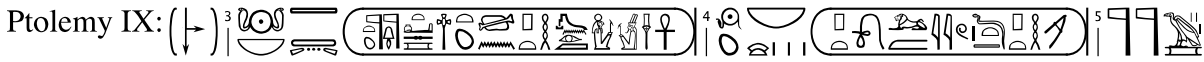

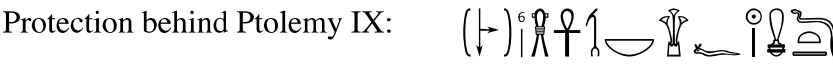

Marginal column behind Ptolemy IX:

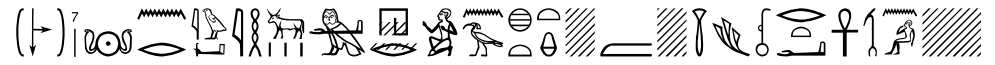

Panebtaui:

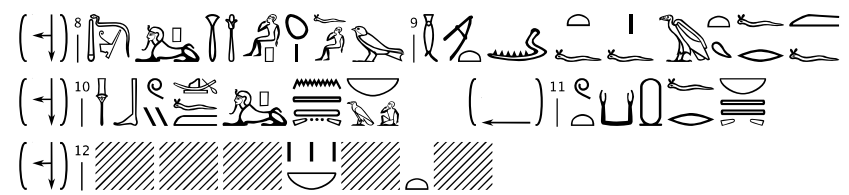

Marginal column behind Panebtaui:

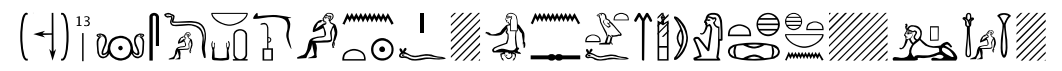

${ }^{1}$ Cf. $W b$ I, 344.20; Wilson, Ptolemaic Lexicon, $253 \mathrm{f}$.

${ }^{2}$ The $w p$-sign must be a miswriting for the word $k 3$ or $t 3 w$. Since reading this sign as $w p$ has no meaning, reading $k 3$ refers to the soul and the provision, both important to the livings. Similar meaning of giving the provisions to the livings/who are upon earth in Leitz, $L G G$ IV, 762-3. I would like to address my thanks to my peer-reviewer who suggested the reading $\underline{t} 3 w$, more meaningful than the others. His suggestion has its parallel (di țw r srk-htyt) in Leitz, $L G G$ IV, 770.

${ }^{3}$ Cf. Leitz, $L G G$ II, 522.

${ }^{4}$ Due to similarity, the word $t 3 w y$ is written as two stones (inrwy). Such way of writing for $h k 3-t 3 w y$ is found in Esna III, 194B. In addition to our case (KO 1063), this title occurs in the offering of myrrh and incense at Athribis (pl. 21 Osiris), Edfou (III, 65, 16; VI, 308, 9, Horus-Behdite and his gold) and Dendera (VII, 21, 15 describes Harseise; IX, 124, 2: describes Harsomtus). Occurrences after Leitz, $L G G \mathrm{~V}, 528 \mathrm{f}$. 


\begin{tabular}{|c|c|c|}
\hline $\mathrm{N}$. & Transliteration & Translation \\
\hline & Title of the offering: & \\
\hline 1 & 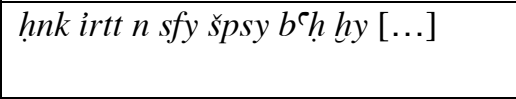 & $\begin{array}{l}\text { Offering of the milk to the noble child (sfy), so that } \\
\text { the }[\ldots] \text { child (hy) floods }\end{array}$ \\
\hline \multirow[t]{2}{*}{2} & 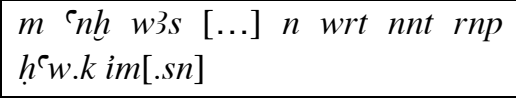 & $\begin{array}{l}\text { with life and dominion }{ }^{1} \text { from the great milk cow, so } \\
\text { that your limbs become rejuvenated through [it]. }\end{array}$ \\
\hline & Ptolemy IX: & \\
\hline 3 & 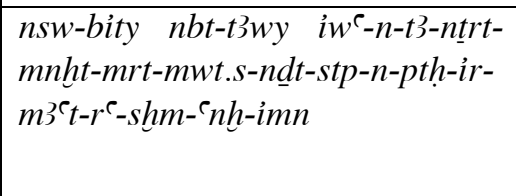 & $\begin{array}{l}\text { King of Upper and Lower Egypt, lord of the Two } \\
\text { Lands: Heir of Euergetis Philometor Soteira, the } \\
\text { chosen of Ptah, who performs Maat of Re, the living } \\
\text { image of Amun. }\end{array}$ \\
\hline 4 & $\begin{array}{l}\text { s3-r } n b-h^{\complement} w \text { Ptwlmys }{ }^{\complement} n h^{3} \underline{d} t \text { mry } \\
\text { pth }\end{array}$ & $\begin{array}{l}\text { Son of Re, Lord of appearance, Ptolemy (IX), who } \\
\text { lives eternally, beloved from Ptah, }\end{array}$ \\
\hline \multirow[t]{2}{*}{5} & ntrwy-mrwy-mwt & Philometor \\
\hline & Protection behind Ptolemy IX: & \\
\hline \multirow[t]{2}{*}{6} & $s 3^{\complement} n h w 3 s n b h 3 . f m i r^{\ulcorner} \underline{d} t$ & $\begin{array}{l}\text { Protection, life and dominion are behind him like } \\
\text { (behind) Re for ever. }\end{array}$ \\
\hline & $\begin{array}{l}\text { Marginal column behind Ptol. } \\
\text { IX: }\end{array}$ & \\
\hline \multirow[t]{2}{*}{7} & $\begin{array}{l}\text { nsw-bity nri ihw mhr n 3ht } m \text { w3 } \underline{d} \\
\text { rdi `nh w3s n sfy [...] }\end{array}$ & $\begin{array}{l}\text { King of Upper and Lower Egypt, protector of the } \\
i h w \text {-cows, }{ }^{4} \text { milker of the } 3 h t \text {-cows }{ }^{5} \text { with fresh milk, } \\
\text { who gives life and dominion (milk) to the child [...] }\end{array}$ \\
\hline & Panebtaui-Pa-Khered: & \\
\hline 8 & $\begin{array}{l}\underline{d} d-m d w \text { in } p 3-n b-t 3 w y-p 3-h r d s f y \\
i k r^{7}\end{array}$ & $\begin{array}{l}\text { Recitation by Panebtaui-Pa-Khered, the excellent } \\
\text { child, }\end{array}$ \\
\hline 9 & bnr mrwt m33-it.f mwt.f r-gs.f & $\begin{array}{l}\text { sweet of love, }{ }^{8} \text { beholder of his father, }{ }^{9} \text { while his } \\
\text { mother is beside him. }\end{array}$ \\
\hline 10 & ${ }^{C b . t w}$ im.f $m$ p3-nb-n-t3wy $k 3^{10}$ & One boasts of him as 'lord-of-the-two-lands'. \\
\hline
\end{tabular}

1 'life and dominion' are names for milk; $W b$ I, 197, 7.

${ }^{2}$ Completion is based on KO 504. In Edfou VII, 230, 4, Horus to the king 'I rejuvenate (srnp) all your body with the sweet milk (' $n h$ and $w 3 s$ ) of Hathor for your throat'. Cf. Edfou VII, 88, 13-16.

${ }^{3}$ The word ' $n h$ is written as a stroke, due to lack of place.

${ }^{4}$ The king is 'he who protects the Ihou' in the Ptolemaic chapel at Deir el-Bahari (DEB 23,2).

${ }^{5} \mathrm{Cf}$. a similar context in Edfou I2 , 452, 17. Budde, Harpare-pa-chered, 234-235. The king is the child of Akhet-cow in the parallel column no. 9 (KO 504) of the inner hypostyle of the main temple (see below).

${ }^{6}$ See $W b$ I, 265, 13 for $w 3 d j$ as fresh milk.

${ }^{7}$ This sign is difficult to definitely recognize, the bird being either $w r$ - or $i k r$-sign. However, other texts texts from Kom Ombo (KO 770 and 783) refer to Panebtaui-Pa-Khered as sfy-ikr. KO 770 is a milkoffering to Panebtaui-Pa-Khered, like the present text, supporting a reading as $i k r$ rather than $w r$.

8 'Sweet of love' is an epithet for Panebtaui in Kom Ombo in a milk offering too e.g. KO 238; 119; 504; 516. This epithet is also seen with other deities, see Leitz, $L G G$ II, pp. 802-804.

${ }^{9}$ Wb 2, 10.1-4; Leitz, $L G G$ III, 199 f.

${ }^{10}$ The $k$-sign is written as $n b$ due to a confusion between both signs (see below). For $k 3$ in this meaning see $\mathrm{Wb}$ 5, 85.6-86.6; Wilson, Ptolemaic Lexicon, 1079. Parallels for k3.tw k3/rn.f are found in the marginal column of Panebtaui in KO 119 and for other deities in Edfou VII, 24, 14; VIII, 84, 15; Opet 183, 2; Opet 260.

- 7 - The Column of Cleopatra III and Ptolemy IX 


\begin{tabular}{|c|c|c|}
\hline 11 & $. t w k 3 . f r n b-t 3 w y$ & $\begin{array}{l}\text { Thus, his name is pronounced as 'lord-of-the-two- } \\
\text { lands'. }\end{array}$ \\
\hline 12 & /// /// /// nb /// /// & {$\left[\begin{array}{llll}\ldots & \ldots & \ldots\end{array}\right]$ all $\left[\begin{array}{lll}\ldots & \ldots\end{array}\right]$} \\
\hline & $\begin{array}{l}\text { Marginal column behind } \\
\text { Panebtaui-Pa-Khered: }\end{array}$ & \\
\hline 13 & 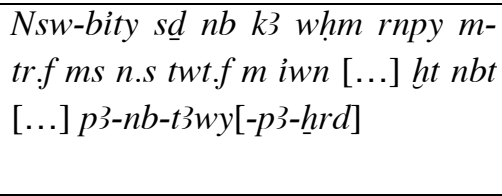 & $\begin{array}{l}\text { King of Upper and Lower Egypt, the child, lord of } \\
\text { name, who becomes young again }{ }^{1} \text { in his time, for } \\
\text { whom his image is born as pillar (moon) }[\ldots] \\
\text { everything [...] Panebtaui[-Pa-Khered]. }\end{array}$ \\
\hline
\end{tabular}

\section{AN ANALYTICAL STUDY OF THE SCENES AND TEXTS ON THE COLUMN:}

After the descriptions and translations of scenes as well as texts on the column, the information is commented upon from a theological, palaeographical, architectural, artistic and historical perspective.

\section{The offerings:}

Since the two main scenes represent two significant offerings, myrrh and milk, a contextual and religious analysis is provided for each offering, further correlating them.

\section{The offering of myrrh to Khonsu-Horus:}

Myrrh is derived from trees and shrubs of the genus Commiphora which is found in South-Arabian and East-African regions. The product is used for fumigation, after it has been dried as red-brown pieces. Ancient Egyptians mainly imported myrrh from Punt, that from the Fifth Dynasty. In some cases, myrrh was exported from Yemen to Syria, then to Egypt. ${ }^{2}$ Because of its special scent, the use of myrrh in fumigation leads to assume a theological association with rejuvenation. Therefore, it is offered to Khonsu-Horus in the present scene (KO 1063). The epithets of Khonsu-Horus on this column confirm his relation to the renewal and rejuvenation at the beginning and the middle of the lunar month (see below).

The title of the current scene indicates that the myrrh was pressed by the god Shemesu after being imported from Punt on the arms of Hathor, to be offered to the nostrils of the child god, here Khonsu-Horus. Shesemu was in charge of such function in the laboratories of the Egyptian temples, where this divine substance was prepared for rituals. ${ }^{3}$ The existence of both Hathor and Shesemu in the title of this offering leads to to assume that Cleopatra III in this scene is identified with both of them, referring to her role in bringing and pressing the myrrh. Her son Ptolemy IX is said to be the image of Shesemu, who presents the myrrh to the divine falcon. ${ }^{4}$ A relationship

\footnotetext{
${ }^{1}$ For the reading of the tongue as whm see Valeurs phon. 267: Urk. VIII, 79, 10. whm rnp in Wb I, 341, $341,8-10$, II, 433, 8-13.

${ }^{2}$ Germer, Myrrhe, in: L̈̈ IV, col. 275f; Germer, Flora, p. 106f.; Koura, 7-Heiligen Öle, $214 f$.

${ }^{3}$ Byl, Essence (online pdf version), 29-30.

${ }^{4}$ Edfou VII, 76, 10-11
} 
between Khonsu and Shesemu is known since the Pyramid Texts, ${ }^{1}$ where Khonsu slays the enemies of the king and Shesemu cooks them in his pot.

\section{The offering of milk to Panebtaui-Pa-Khered:}

The offering of milk is known since the Old Kingdom onward. ${ }^{2}$ This ritual occurs frequently in Egyptian temples dating to the Greco-Roman period, and is mostly associated with female ${ }^{3}$ and child deities. It is indeed equalled to the suckling, in reference to nourishment, which strengthens the body of the child. According to a text from Edfou, ${ }^{4}$ it is offered in Chemmis to the child who appears as a falcon in his nest with the aim of making his arms strong against his enemies. The whiteness of milk refers clearly to purity, making the child pure and protected. In addition, milk is associated with regeneration and rejuvenation due to the assimilation between the child-god (the future ruler) and the sun god Ra, who reappears every day. ${ }^{5}$

In our scene (KO 1064), milk described as ' $n h$ and $w 3 s$ supports the concept that it provides the child with both life and dominion, which are necessary for the divine child during his childhood and kingship. The title here declares that the child god floods with both life and dominion and his body is rejuvenated through this milk. Providing ' $n h$ and $w 3 s$, milk, to the child is the responsibility of the king in his marginal column. ${ }^{6}$ In the same marginal column, the king is also in charge of protecting the $i h w$-cows and he is the milker of the 3ht-cows. Both functions guarantee the offering of the milk. Mentioning cows in this context reminds to Hathor, who plays as a key between milk and rejuvenation, as she is the mother of the dead, as well as the cow which produces milk in reality. ${ }^{7}$

\section{Myrrh and milk offerings in one context:}

The two offerings of milk and myrrh are associated on the present column, and this recurs in other cases. For instance, Ptolemy VIII offers milk to Panebtaui and myrrh to Tasenetneferet on column 9 of the inner hypostyle (KO 504-503) of the main temple of Kom Ombo. This association of both offerings is probably due to their use as nourishments, milk through the mouth of the gods and myrrh through their nostrils. Each produces vapour at the moment of offering, the milk from its jars and the myrrh from the fumigator. Both are also symbols of rejuvenation. As mentioned, Hathor is

\footnotetext{
${ }^{1}$ PT 273-274.

${ }^{2}$ Milk is offered from the Old Kingdom to deceased and gods. Guglielmi, Milchopfer, in $L \ddot{A}$ IV, col. $127 f$.

${ }^{3}$ Offering milk to female goddesses indirectly provided it to the child god. See Cassor-Pfeiffer, Milch und Windeln, 80 , note 35 .

${ }^{4}$ Edfou VII, 65, 8-13.

${ }^{5}$ Details on milk and the child in Poo, Liquids, 3f; Guglielmi, Milchopfer, in $L \ddot{A}$ IV, col. 127f; CassorPfeiffer, Milch und Windeln, 82-84; Budde, Harpare-pa-chered, 61f; id., Götterkind, 208; Sandri, Har-Pa-Chered, 180. For the milk-offering in mammisis, Daumas, Mammisis, 175-206.

${ }^{6}$ In texts outside of Kom Ombo, the king speaks to the god: 'I rejuvenate your limbs with life and dominion (milk) of Hathor' Edfou VII, 230, 4; Edfou VII, 88, 16; Edfou VII, 123, 10-12. In Kom Ombo (GKO 164, 1), the king offers milk ${ }^{`} n h-w 3 s$ to Panebtaui.

${ }^{7}$ Cf. Pätznick, Le lait dans l'Égypte ancienne, 173-198.
}

- 9 - The Column of Cleopatra III and Ptolemy IX 
the key figure for rejuvenation in both offerings due to her close association with motherhood and milk giving on one hand and with Punt on the other hand. Since she is the lady of Punt, where myrrh is imported from, as mentioned in the text.

\section{The divine children of Kom Ombo and their epithets:}

Section a of the current column contains four divine children. They all wear the side lock, being seated on papyrus plants, pointed their finger to the mouth, and holding the flail in the other hand. Such attitude is generally familiar for divine children. A bandeau-text from the mammisi of Kellis describes the god Tutu as 'the old one who appears as a child ... seated upon a lotus flower with his right finger in his mouth and the crook and the flail in his hand'. Kaper concluded that Tutu appears as a king in the Mammisi of Kellis. ${ }^{1}$ In our column, the divine children are not seated upon lotus but upon papyrus flowers. While emerging from the lotus flower is associated with the primeval creation at Hermopolis, papyri refer to the marshes, where Horus was born and grew up. Moreover, Horus is described in several texts as 'He who is on his $w 3 \underline{d}$ papyrus stem'.2

Thus, the divine children of Kom Ombo are identified here to Horus, the prototype of childhood and kingship. Such kingship could thus also be proclaimed for them. In addition to their childish attitude in the lower register of this column, they are depicted in the two main scenes, but without the finger towards the mouth. Both of them hold the flail and the $w 3 s$-sceptre, i.e. the symbols of royalty. Khonsu holds the crook. Furthermore, two of the seated children on the lower register wear the feathered crown of Amun, the king of all gods. One of these two deities (no. 8) is described as 'Panebtaui-Pa-Khered' to confirm their kingship, which is a classical theme in the theology of birth houses. ${ }^{3}$

Both Khonsu and Panebtaui carry significant epithets in our column, some of which are familiar, such as 'lord of Kom Ombo' for Khonsu and 'sweet of love' for Panebtaui. They are also described with other specific epithets, presented in the following section to highlight the association of these epithets with divine children and the offerings.

\section{The epithets of Khonsu-Horus (sec. c right 6-12):}

As a lunar god, Khonsu-Horus is described as 'lord of joy' in reference to his syncretized form at Kom Ombo ${ }^{4}$ and other cult places. ${ }^{5}$ This lunar god ${ }^{6}$ obtains this epithet due to his beautiful shine at night, which is cheerful for people. He is also

\footnotetext{
${ }^{1}$ Kaper, God Tutu, 280-281 [R-60].

${ }^{2}$ Instances in Leitz, $L G G \mathrm{~V}, 275-276$.

${ }^{3}$ Daumas, Mammisis, p. 493.

${ }^{4}$ e.g. KO 19; 57; 202; 921.

${ }^{5}$ Details in Leitz, $L G G$ II, 559-561.

${ }^{6}$ Generally, for the role and the symbols of the moon in the temples of Greco-Roman period, see Altmann-Wendling MondSymbolik.
} 
'jubilee pillar' in the present text, which refers to all moon deities. ${ }^{1}$ This shiny form of Khonsu-Horus is confirmed through another epithet, i.e. 'illuminator of the two lands like Akhty'. On the gate of Khonsu at Karnak, ${ }^{2}$ Khonsu-Re is described as illuminator of the two lands in an offering of myrrh, similarly to the present case study.

This illumination as an epithet to Khonsu as a lunar followed by the phrase 'like Akhty' is significant, because it brings to mind the role of the lunar god as a vizier and representative to the solar god, here Akhty, in the Egyptian mythology. Thoth, the lunar god, is the prototypical vizier of Re, the solar god. Therefore, Khonsu-Horus, identified with Thoth, is described here as 'heart', 'tongue' and 'opener of the years', which recalls the god Thoth and his association with the performance of both cult and funeral ceremonies. Such ceremonies appear in the column; filling the $w \underline{d} 3 t$-eye is a job of Khonsu-Horus 'whose majesty becomes young at the beginning of each month and he who fills the $w d \underline{t} t$-Eye in every half-month-festival'. On his gate at Karnak, Khonsu is also responsible for 'filling the eye' ${ }^{4}$ The connection between the eye and the moon is obvious in Pap. Boulaq 3, line $x+9,8$, where it is said: 'your radiance on earth is like the moon which fills the $w d \underline{d} 3$-eye'. ${ }^{5}$ Thus, 'filling the eye' refers to completing the moon on the $s d m t$-festival 'half-month=day 15 ' according to the present text. This filling or completion of the moon ( $=w \underline{d} 3 t$-eye) is in turn associated with the mummification. ${ }^{6}$ Similarly, Osiris, also a moon deity, ${ }^{7}$ becomes young 'at the the occasion of the half-moon festival ${ }^{8}$ and 'rejuvenated at the occasion of the new moon'. ${ }^{9}$ Filling the eye and mummification are very known aspects of the renewals of of the moon god at the beginning of the month, when it disappears and is then reborn, and on day 15 at its completion and consequently its full-radiance.

Other epithets for Khonsu-Horus support this double renewal, where he is described as 'he who repeats his appearance' (c. 12) and 'lord of transformations' (c. 9). ${ }^{10}$ Both are typical for the moon deity and reflect how this deity begins very small (crescent) and becomes bigger each night, until it is complete and then rejuvenates each lunar month.

${ }^{1}$ Wb 1, 53.17; Wilson, Ptolemaic Lexicon, p. 52.

${ }^{2}$ Clère, porte d'Évergète, pl. 26. 'Illuminator of the two land' with other deities, Leitz, LGG VI, 484.

${ }^{3}$ Leitz, $L G G$ II, 351.

${ }^{4}$ See Leitz, $L G G$ III, p. 362. For filling the eye of the moon with minerals (myrrh in our case) and plants, see also Altmann-Wendling, MondSymbolik, 293-338.

${ }^{5}$ After Töpfer, Balsamierungsritual, 177-178. Beside $w \underline{d} 3 t$ in the same context, other words for the 'eye' occur e.g. irt- hr, 3ht, dbhww, irt-ỉbt. Wb II, 116.9-11.

${ }^{6}$ Such association between mummification and filling the eye is confirmed in another text from Kom Ombo (921) on both each and half of the lunar month. Khonsu-Horus is called 'the child (hy) at the beginning of the month and who is venerable on the day 15 , while his body is hidden each day'.

${ }^{7}$ For the moon as Osiris in particular at Dendera and in the funeral papyri as well as the death and rejuvenation of Osiris, see in details: Altmann-Wendling, MondSymbolik, 53-56; 529-549; 681-697; 713.

${ }^{8}$ Opet I, 44 right.

${ }^{9}$ Opet I, 81. According to the Book of Dead 125, intro. 19, 23, the completion of the eye occurs in Heliopolis.

${ }^{10}$ Cf. Leitz, LGG III, 714. Cf. the gate of Ptolemy III at Karnak (Clère, Porte d'Evergete, pl. 72).

- 11 - The Column of Cleopatra III and Ptolemy IX 
Khonsu-Horus appears here not only in his lunar aspect or that of vizier, representative, vice of the creator god, but also as a creator himself. He is described as (9-10) 'who provides the provision for the throat' and 'He who perpetuates the malechild in his egg'. 'The second epithet is significant, as it mainly refers to creator gods such as Amun(-Re $)^{2}$ and Khnum(-Re), ${ }^{3}$ who are regularly associated with birth houses. At Kom Ombo, Haroeris is similarly described as 'he who perpetuates the male child in the womb of his mother' ${ }^{4}$ The womb is synonym to the egg in this case, case, as both are the place of the child before birth. Moreover, describing the egg as štyt is remarkable too, as the inside of this egg is hidden. It also refers to the precreation as a hidden phase also in reference to the world before its creation, according to the Hermopolitan theology.

\section{The epithets of Panebtaui-Pa-Khered on the column:}

On this column, Panebtaui-Pa-Khered is described as 'the child' in various Egyptian terms: $s f y-s p s y, s f y$-ikr, hy and $s \underline{d}$, which must have a significance. The epithet $s f y-$ spsy (noble child) is well known for divine children in all cult places. ${ }^{5}$ As for Kom Ombo, Panebtaui-Pa-Khered is described as sfy-řpsy in two scenes of milk offering, as well as on columns. The first case is KO 119 (column 1 of the courtyard), while the other case is KO 504 (column 9 of the inner hypostyle). Milk-offering in KO 504 is significant, as it exists together with the offering of myrrh (KO 503), similarly to the examined column (see below). Moreover, KO 504 contains sfy-ikr 'excellent child' for Panebtaui-Pa-Khered, which occurs in this text too. This epithet refers to Panebtaui in two other texts from Kom Ombo, one of which is a milk offering to Panebtaui-PaKhered. ${ }^{6}$ Other child gods from outside Kom Ombo are described as $s f y$-ikr in birth houses. ${ }^{7}$ The term sfy is then followed by either $\breve{s} s y$ or $i k r$ to describe Panebtaui as a child mostly in birthing contexts, due to its occurrence to both milk-offering and birth houses. ${ }^{8}$ The adjective $i k r$ also refers to the faultless nature ${ }^{9}$ of the child, while $\check{s} p s y$ is is close to his sincereness. ${ }^{10}$ Two other usual terms for the child gods are $h y^{1}$ and $s \underline{d},{ }^{2}$

\footnotetext{
${ }^{1}$ Cf. Leitz, $L G G$ VI, 185.

${ }^{2}$ In Mammisi Dendera e.g. 31, 6; 133, 1-2; 152, 10; 268, 5-6.

${ }^{3}$ Esna III, 225, 8; 249, 1; 318, 10; 388, 9.

${ }^{4} \mathrm{GKO} 228,5$.

${ }^{5}$ Leitz, $L G G$ VI, 298ff. especially in milk offering to the divine children e.g. Ihi-Our in Dendera VI, 13, 3 and to Harsamtus-Pa-Khered in the Mammisi Dendera 246, 11.

${ }^{6} \mathrm{GKO}$ 164, 1 (milk offering); 181, 1 (amulet offering).

${ }^{7}$ E.g. Harsamtus-Pa-Khered in the Mammisi of Edfou 84, 18; 151, 17 (milk offering). Dendera Mammisi 184, 11. Arment Mammisi LD IV, 60b left and Mammisi Philae II, 307, 10; 393, 8.

${ }^{8}$ According to Leitz ( $L G G$ VI, p. 299), the epithet 'sfy-Spsy' describes Panebtaui-Pa-Khered in five milk offerings, four from Kom Ombo and one from Edfou (cf. Edfou VIII, 105, 7). Three milk offering could be confirmed, namely KO 119, 504 and the present 1064. The fourth (KO 770) in the Belegstellen of Leitz refers to Panebtaui-Pa-Khered as sfy-ik kr not sfy-̌̌psy.

${ }^{9}$ Wb I, 137. Edel (Ägyptische Ärzte, p. 57f) assumes that the term 'ikr' refers to competence/excellence in particular of medicines. The term has its parallel in the Akkadian and Assyrian languages.

${ }^{10} \mathrm{~Wb}$ IV, 445.
} 
which are not limited to milk offering like the previous ones. However, they are used in this column's text as synonyms in order to avoid boredom and to enrich the meanings.

On the other hand, Panebtaui-Pa-Khered is described as 'beholder of his father, while his mother is beside him'. Such two epithets seem to reflect a social aspect or behaviour of the child towards his parents. As aforementioned, each divine child is identified with the prototype Horus, who was in charge of watching and keeping his father Osiris safe against enemies, since this epithet is mainly funerary. ${ }^{3}$ The epithet 'while his mother is beside him' completes the meaning of the last one, as the mother is Isis, the ideal mother, who supported Horus. ${ }^{4}$ Furthermore, the name 'Panebtaui' issued after the desire of his father and mother to be lord of the two lands. Therefore, this passage of the text (c. 10) provides a different writing of the name, as 'Paneb-ntaui' by adding the genitival adjective ' $n$ '. In such a way, Panebtaui is aptly named 'lord of two lands' in reference to his kingship in the birth house of Kom Ombo.

\section{A general note about the epithets of Panebtaui-Pa-Khered and Khonsu-Horus on the column:}

Despite the lost part in the marginal column behind Panebtaui-Pa-Khered, two important epithets 'who becomes young again in his time' and 'for whom his image is born as pillar or moon' are of interest. Pillar/moon and renewal are discussed above with Khonsu-Horus and his lunar aspect. Both epithets lead to find out the remarkable correlation between the epithets on both sides of the column. While Khonsu-Horus on the right side has monthly renewal, thanks to his lunar aspect, Panebtaui-Pa-Khered seems to have a daily solar renewal. In addition to the aforementioned relation between Khonsu and Akhty (the sun god), this assumption is supported by the depiction of disks on the heads of these divine children. Khonsu-Horus has the lunardisk, while Panebtaui-Pa-Khered has the solar-disk. Both disks refer to the moon and the sun respectively.

\section{Palaeographical epigraphic notes on some Hieroglyphic signs on the column:}

The texts on the column include hieroglyphic signs which are in different or unusual writing. Therefore, a palaeographical note on these signs is presented here to investigate each sign and its variations. The following table shows selected examples.

\footnotetext{
${ }^{1}$ Leitz, $L G G \mathrm{~V}, 615 \mathrm{f}$.

${ }^{2}$ Leitz, $L G G$ VI, p. $723 \mathrm{f}$ (present text as nr. 23).

${ }^{3} \mathrm{~Wb}$ 2, 10.1-4; Leitz, $L G G$ III, $199 \mathrm{f}$.

${ }^{4}$ Leitz, LGG III, 201.
}

- 13 - The Column of Cleopatra III and Ptolemy IX 


\begin{tabular}{|c|c|c|c|c|c|c|c|}
\hline $\begin{array}{c}\text { Hiero- } \\
\text { sign }\end{array}$ & Sign list & $\begin{array}{c}\text { Shape } \\
1 \\
\end{array}$ & $\begin{array}{c}\text { Shape } \\
2\end{array}$ & Shape 3 & $\begin{array}{c}\text { Shape } \\
4\end{array}$ & $\begin{array}{c}\text { Shape } \\
5 \\
\end{array}$ & Remarks \\
\hline \multirow{2}{*}{$\approx$} & I 9 & 兴 & $x$ & $\checkmark r$ & & $x$ & \multirow[b]{2}{*}{$\begin{array}{l}\text { The horns of the viper are } \\
\text { always represented, while } \\
\text { its body is sometimes } \\
\text { incised as a thin single } \\
\text { line or a very short double } \\
\text { line. }\end{array}$} \\
\hline & loc & $\mathrm{a} 1^{1}$ & a $7^{2}$ & $\mathrm{c} \mathrm{A} 2^{3}$ & c B 9 & c B 9 & \\
\hline \multirow[t]{2}{*}{11} & G 14 & & & & & & \multirow{2}{*}{$\begin{array}{l}\text { The vulture is detailed } \\
\text { only in the bandeau-text, } \\
\text { while it is identified only } \\
\text { through its meaning and } \\
\text { context in other cases. }\end{array}$} \\
\hline & loc & $\mathrm{b}$ & $\mathrm{B}$ & c right 4 & c left 5 & c left 9 & \\
\hline \multirow[t]{2}{*}{$B$} & G 43 & & & & & & \multirow{2}{*}{$\begin{array}{l}\text { The quail chick appears } \\
\text { similar to } i k r \sqrt{ } \mathrm{c} \text { left } \\
8 \text {. }\end{array}$} \\
\hline & loc & c left 2 & c left 7 & & & & \\
\hline \multirow[t]{2}{*}{8} & V 28 & 8 & 25 & 8 & & & \multirow{2}{*}{$\begin{array}{l}\text { The wick of twisted flask } \\
\text { has three shapes, either } \\
\text { crossed or non-crossed } \\
\text { lines. }\end{array}$} \\
\hline & loc & $b^{4}$ & $\mathrm{~b}^{5}$ & c B 7 & & & \\
\hline \multirow[t]{2}{*}{-} & O 34 & & $\square$ & $\frac{n n}{v i v}$ & & & \multirow{2}{*}{$\begin{array}{l}\text { The bolt is written in three } \\
\text { variations, two of which } \\
\text { are confused with the } t 3- \\
\text { sign. The two locks in its } \\
\text { middle appear only in c B } \\
\text { 13. }\end{array}$} \\
\hline & loc & a 3 & $\begin{array}{l}\text { c A } \\
10^{6}\end{array}$ & c B 13 & & & \\
\hline \multirow[t]{2}{*}{$\ldots$} & N 16 & 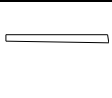 & & 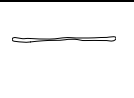 & $\square$ & $\hookrightarrow$ & \multirow{2}{*}{$\begin{array}{l}\text { The flat alluvial land lacks } \\
\text { the grains of sand beneath } \\
\text { it in all given cases. } \\
\text { Moreover, it is confused } \\
\text { with the inr-sign in c B } 6 \text {. }\end{array}$} \\
\hline & loc & a 1 & a $3^{7}$ & $\mathrm{~b}$ & c A 12 & c B 6 & \\
\hline
\end{tabular}

Based on the above table, one suggests that some signs were confused with others, while in instances signs were written in a shape similar to their hieratic writing. As for the confusion between signs, it occurs due to their similarity. For instance, the $k$-sign (sign-list V 31) is written as $n b$ (sign-list V 30) in c. 10 left scene. For lack of place, the $t 3$-sign is written sometimes as a simple flat line similar to the $s$-sign especially in cases of royal names. Generally, these epigraphic errors were due to the small size of

${ }^{1}$ Cf. similar shapes on the column in c A 2, c A 5, c B 9, c B 10.

${ }^{2}$ Similar also on the column in c B 8, c B 13.

${ }^{3} \mathrm{Cf}$. on the column c A 5, c A 12, c B 1, c B 6, c B 11 .

${ }^{4}$ Similar on the column in c A 5.

${ }^{5}$ Similar on the column in c B 3 and 4.

${ }^{6}$ Cf. Valeurs Phon. vol. III, p. 449.

${ }^{7}$ This shape of the $t 3$-sign occurs in several places on the column. 
signs inscribed in a limited space. The ripple of water (sign list N 35) occurs in two different forms with $\sim 4$ or $\sim 3$ waves.

\section{Architectural and artistic notes on the column:}

When this column was revealed (between 1893 and 1914), a photograph of the team (Fig. 4) was taken, of them sat on its cylindric parts behind the screen walls of the Mammisi of Kom Ombo. Another old photograph (Fig. 2a) ${ }^{1}$ displays four pieces of this column, and a fifth as a base, combined together before being imported to the Egyptian Museum in Cairo. The upper fourth piece in this old photo shows a palm style. However, it has been apparently replaced by another one of the papyrus bundle stalks as the current state shows. This latter piece of the papyrus bundle stalks indicates a composite papyrus lily capital, ${ }^{2}$ which could be added to our column as a sixth part (Fig. 5 and 6c). The northern space at Kom Ombo complex stores several blocks that were discovered since the work of de Morgan until now. Among these blocks, a capital is identified; it is a beautiful example of the lily capitals (Fig. 5) and matches our column perfectly. Thus, the column under study contained at least six cylindrical pieces in its original size and was of the papyrus style.

A question arises here about the exact location of this column. Based on the aforementioned photo of the team, the pieces were found behind the screen walls of the birth house of Kom Ombo (Fig. 6a). Thus, four columns (KO 1063-1070) were erected in two rows in the hypostyle behind these screen walls. The studied column (JE 45072) might have been located in the second inner row beside the axis to the outer vestibule (Fig. 6b). This theory is supported by comparing this column with column 9 (KO 503-504) in the inner hypostyle of the main temple due to their similarity in content, as both include two typical offerings, myrrh and milk. Moreover, the base of our column has been cut in one of its sides in earlier times (Fig. 1). According to the 'grammaire du temple', the king is always depicted looking in the direction of the inside of the temples. Therefore, KO 1063 was located to the west, while KO 1064 was to the east.

The current reconstruction of the column and then the edifice of the birth house of Kom Ombo is an update of the older plans and descriptions of the mammisi of Kom Ombo (e.g. Fig. 6a), which did not show columns inside the structure. ${ }^{3}$ Unlike other

\footnotetext{
${ }^{1}$ de Morgan et al, Kom Ombos, vol. III, p. 345

${ }^{2}$ For the composite capitals since the Eighteenth Dynasty, see Jaroši \& Arnold Säule, in: $L \ddot{A} \mathrm{~V}$, col. 347 (7) Abb. 11 on sp. 346; Yasuoka, Altägyptischen Säulen, 77-81.

${ }^{3}$ E.g. Daumas, Geburtshaus, in: $L \ddot{A}$ II, col. 463; Gubub (Kom Ombo, in: LÄ III, col. 679 plan on $677-$ $678, \mathrm{~K}$ ) describes very shortly the hypostyle as 'pronaos with column ceiling (destroyed ceiling and displaced columns)'. This short reference of Gutbub to columns in the Mammisi of Kom Ombo might be based on the reconstruction of the Description de l'Égypte (1820: Vol 1, Pl. 46), which shows the façade of this Mammisi with screen walls, between which Hathoric columns are visible at that time. However, this reconstruction does not display the hypostyle. Plans of the Mammisi of Kom Ombo without columns are found in de Morgan et al, Kom Ombos, vol. I, 28-30; Arnold, Temples of the Last Pharaohs, 202.
}

- 15 - The Column of Cleopatra III and Ptolemy IX 
Mammisis, the birth house of Kom Ombo has no ambulatory, ${ }^{1}$ but a pillared hypostyle hall as reconstructed.

The height of this column is rather small, totalling with its capital ca. $260 \mathrm{~cm}$. Upon this capital, one or two other pieces could also have been added, as there may have been between the capital and the architrave below the ceiling, an abacus with figures of $\mathrm{Bes}^{2}$ or Hathoric faces on the four sides, or even both together. The columns of the Mammisi of Philae are topped by faces of Hathor on four sides, upon which her naos is found, instead of an abacus.

This column from Kom Ombo also has a decorative frieze of 12 Hathoric faces (sec. $d$ and Fig. 7a), which are depicted on some columns of the southern ambulatories of the Mammisis at Edfu and at Dendera. This decorative motif of Hathoric faces seems to be found only on columns of Mammisis. It refers to the close relationship between Hathor and the birth houses.

Another interesting decorative motif is depicted on the lower part of this column, i.e. the rekhyt-birds adoring the seated divine children (sec. a). Usually, a star is decorated beneath the elbow of the rekhyt-bird to show the rebus 'rekhyt-nb-dw3' meaning 'all the rekhyt-people adore'. ${ }^{3}$ This time, the star is not inscribed and the meaning of 'adore' is apparently alluded to through the attitude of the upraised human arms of these birds. The depiction of rekhyt-birds in relation to birth houses and birth cycles is significant. Indeed, an important scene in the Mammisi of Philae shows these rekhyts represented as humans in a jubilation attitude adoring the divine child after coming out from the shrine in reference to the kingship of this divine child. ${ }^{4}$ According to the Mammisi of Edfu, ${ }^{5}$ Thoth was in charge to call these rekhyts to come and see the new born child. Thus, representations of these rekhyt-birds on this column point to the kingship of divine children at Kom Ombo.

\section{The date of the column:}

One can date the column to the co-reign of Ptolemy IX and Cleopatra III according to their cartouches and figures. However, as their co-reign is long (116-107 BC), this is not precise enough. The reign of Ptolemy IX could be divided into three phases: the first phase (triple-monarchy 116-115 BC) with Cleopatra II and III, ${ }^{6}$ the second phase

\footnotetext{
${ }^{1}$ Due to their symbolism for marshes, columns were distributed not inside the birth houses but between screen walls around the naos under the architectural term 'ambulatory'. This ambulatory appeared for the first time during the reign of Ptolemy VIII at Edfu. Daumas, Geburtshaus, in: LÄ II, col. 463.

${ }^{2}$ For Bes-figures upon capitals in the mammisi of Edfu, see https://www.aegyptologie.unimainz.de/das-mammisi-von-edfu-2/ (visited on 29 May 2020).

${ }^{3}$ Such rebus appeared first during the reign of Hatshepsut and continued through the Roman period. For this rebus see Bell, 'Divine' Temple, 127-84; Houlihan, Birds of Ancient Egypt, 93-6; Griffin, Images of the Rekhyt, 45-50. Recently (2018), Kenneth Griffin published his PhD degree on these rekhyt-people.

${ }^{4}$ For this scene from Philae see Budde, Harpare-pa-chered, $18 \mathrm{f}$.

${ }^{5}$ Mammisi Edfou, pl. 13 and 22, 11-15; Budde, Harpare-pa-chered, $18 \mathrm{f}$

${ }^{6}$ The triple-monarchy is emphasised in a scene in the western room of the eastern wing of the $1^{\text {st }}$ pylon
} 
(bi-monarchy 115-107 BC) with Cleopatra III, while the third alone as Soter II $^{1}$ (88$81 \mathrm{BC}$ ). Both the triple-monarchy and the sole reign are excluded, because Ptolemy IX appears with Cleopatra III on this column, dating it to between 115 and 107 BC. They also appear together in other documents from Kom Ombo or from other cult places.

The co-reign of Ptolemy IX and his mother Cleopatra III is expressed in selected scenes at Kom Ombo. ${ }^{2}$ In addition to this case (KO 1063-1064), the other columns (KO 1065-1070) contain their cartouches and figures. Moreover, they are depicted in the main temple of Kom Ombo carrying offerings to Haroeris (418) and to Sobek (419-420).

Unfortunately, the ruined state of the Mammisi at Kom Ombo does not allow to know whether they were depicted on the walls of the courtyard. They only appear on the cylindrical blocks found in the Mammisi as mentioned. The four columns contain eight scenes: Ptolemy IX appears five times (KO 1064, 1065, 1066, 1068 and 1070), his mother three times (KO 1063, 1067 and 1079) every time to his side. However, their cartouches are written on the bandeau-texts of all columns (KO 1063-1070) regardless to the presence of their figures in the main scenes of the columns, due to the coregency.

In August $115 \mathrm{BC}$, Ptolemy IX took part in the festival of the rising Nile on the island of Elephantine. ${ }^{3} \mathrm{He}$ visited cult centres in Upper Egypt e.g. Thebes and Kom Ombo. This historical visit could be the most suitable occasion of erecting and decorating the columns from the Mammisi at Kom Ombo. Based on the latter argument, the column dates to August $115 \mathrm{BC}$.

at Philae, where Ptolemy IX is accompanied by two Cleopatras. They are II and III for de Meulenaere, Ptolémée IX Soter II à Kalabcha, 104-105. For the co-reign of Ptolemy IX and the two Cleopatras II and III see Murnane, Coregencies, 99- 101; Ritner, Ptolemy IX (Soter II) at Thebes, 2; Huss, Ägypten in hellenistischer Zeit, 630-636 with mistake of the Ptolemies, i.e. Huss calls Ptolemy IX, VIII.

${ }^{1}$ Cleopatra III exiled Ptolemy IX and appointed his junior brother Ptolemy X. In 88, Ptolemy IX came back and ruled alone. Therefore, he changed his epithets to 'Soter'. See the following footnote.

${ }^{2}$ As the current research focuses on Kom Ombo, other inscriptions of Ptolemy IX and Cleopatra III are excluded. For Ptolemy IX and Cleopatra III in documents mainly from Thebes, see the study of Ritner, Ptolemy IX (Soter II) at Thebes, a pdf-online-version (accessed on 8 April 2020): https://oi.uchicago.edu/sites/oi.uchicago.edu/files/uploads/shared/docs/ptolemy soter II at thebes.pdf. Ritner is concerned interestingly with the phraseology of the royal praenomen and its modification for propagandistic reasons for both Ptolemy IX and his mother. Götte, Individualcharakteristik, 63-80. Ritner also reprinted this online version on 2011 with the title: Ptolemy IX (Soter II) at Thebes. In Dorman, Peter F. and Betsy M. Bryan (eds), Perspectives on Ptolemaic Thebes: papers from the Theban Workshop 2006, 97-114.

${ }^{3}$ Hölbl, Ptolemaic Empire, 205-206.

- 17 - The Column of Cleopatra III and Ptolemy IX 


\section{BIBLIOGRAPHY}

1. Abdelhalim, A., 'Notes on the Bandeau-Texts of Columns of Kom Ombo Temple,' in: BCPS, Vol. 36, Issue 1, (2019), 287-304.

2. Altmann-Wendling, V., MondSymbolik - MondWissen. Lunare Konzepte in den ägyptischen Tempeln griechisch-römischer Zeit (SSR 22), Wiesbaden, (2018).

3. Arnold, D., Temples of the Last Pharaohs, Oxford University Press ,(1999).

4. Bell, L., 'The New Kingdom 'Divine' Temple,' in: Byron E Shafer (ed.), Temples of Ancient Egypt, London, (1998), 127-84.

5. Bevan, E., A History of Egypt under the Ptolemaic Dynasty, New York (1927).

6. Budde, D., Das Götterkind im Tempel, in der Stadt und im Weltgebäude. Eine Studie zu drei Kultobjekten der Hathor von Dendera und zur Theologie der Kindgötter im griechisch-römischen Ägypten, Darmstadt/Mainz, (2011).

7. — ' 'Harpare-pa-chered: ein ägyptisches Götterkind im Theben der Spätzeit und griechisch-römischen Epoche,' in: D. Budde, S. Sandri, U. Verhoeven (eds.), Kindgötter im Ägypten der griechisch-römischen Zeit. Zeugnisse aus Stadt und Templel als Spiegel des interkulturellen Kontakts, OLA 128, 2003, 15-110.

8. — 'Kommt und seht das Kind: Kindgötter im Festgeschehen der griechischrömischen Geburtshäuser Ägyptens,' in: D. Prechel (ed.), Fest und Eid: Instrumente der Herrschaftssicherung im Alten Orient, Kulturelle und sprachliche Kontakte 3, (2008), 13-48

9. Byl, Sh. A., The Essence and Use of Perfume in Ancient Egypt, 2012 pdf online, 2930.

10. Cassor-Pfeiffer, Silke, Milch und Windeln für das Horuskind. Bemerkungen zur Szene Opet I, 133-134 (= KIU 2011) und ihrem rituellen Kontext, in: $C d K$ 16, (2017), 73-91.

11. Cassor-Pfeiffer, S., 'Zur Reflexion ptolemäischer Geschichte in den ägyptischen Tempeln unter Ptolemaios IX. Philometor II./Soter II. und Ptolemaios X. Alexander I. (116-80 v. Chr.). Teil 1: Die Bau- und Dekorationstätigkeit,' in: JEH 1 (2008), 2177.

12. — ' 'Zur Reflexion ptolemäischer Geschichte in den ägyptischen Tempeln unter Ptolemaios IX. Philometor II./Soter II. und Ptolemaios X. Alexander I. (116-80 v. Chr.). Teil 2: Kleopatra III. und Kleopatra Berenike III. im Spiegel der Tempelreliefs,' in: JEH 1, (2008), 235-265.

13. Clère, P., La Porte d'Evergète à Karnak $2^{\text {ème }}$ partie Texte imprimé planches, Cairo, (1961).

14. Daressy, G., 'Note sur des bas-reliefs du temple de Deir el-Médineh,',in: BIFAO 6, (1906), 71-74.

15. Daumas, F., Geburtshaus, in: $L \ddot{A}$ II, cols. $462-475$.

16. Daumas, F., Les mammisis des temples égyptiens, Paris, (1958).

17. de Meulenaere, H., Ptolémée IX Soter II à Kalabcha,', in: CdÉ 36/71, (1961), 98105.

18. de Morgan et. al. 1895: de Morgan J. et. al., Kom Ombos, 2 vols, Vienne, (1895).

19. du Bourguet, P., Le Temple de Deir el-Médîna, Cairo, (2002).

20. Edel, E., Ägyptische Ärzte und ägyptische Medizin am hethitischen Königshof, Opladen, (1976).

21. Germer, R., Myrrhe, Myrrhe, in: L̈̈ IV, cols. 275-276.

22. --------, Flora des pharaonischen Ägypten, Mainz, (1985).

23. GKO: Gutbub, A., Kôm Ombo I Les inscriptions du naos (sanctuaires, salle de l'ennéade, salle des offrandes, couloir mystérieux), Cairo, (1995).

24. Götte, K., Eine 'Individualcharakteristik ptolemäischer Herrscher anhand der 
Epitheta-Sequenzen beim Weinopfer,', in: RdÉ 37, (1986),63-80.

25. Griffin, Kenneth, "All the rhyt-people adore": the role of the rekhyt-people in Egyptian religion, GHP Egyptology 29, London, (2018).

26. Griffin, K., 'Images of the Rekhyt from Ancient Egypt,' in: AE ,Oct/Nov. (2006), 4550.

27. Gubub, A., Kom Ombo, in: $L \ddot{A}$ III, cols. 675-683.

28. Guglielmi, W., Milchopfer, in $L \ddot{A}$ IV, cols. 127-128.

29. Hölbl, G., A history of the Ptolemaic Empire. Translated by T. Saavedra, London, (2001).

30. Houlihan, P.F., and Goodman, S. M., The Birds of Ancient Egypt, Cairo, (1988).

31. Jaroši . P \& Dieter A., Säule, in: $L \ddot{A} \mathrm{~V}$, cols. 343-348.

32. KAPER, O, The Egyptian God Tutu. A study of the Sphinx-god and Master of Demons with a Corpus of Monuments, Leuven, (2003).

33. Koura, B., Die 7-Heiligen Öle und andere Öl- und Fettnamen. Eine lexikographische Untersuchung zu den Bezeichnungen von Ölen, Fetten und Salben bei den Alten Ägyptern von der Frühzeit bis zum Anfang der Ptolemäerzeit (von 3000 v. Chr. - ca. 305 v. Chr.), Aachen, (1999).

34. Kurth, D., Ptolemaois, in: $L \ddot{A}$ IV, cols. 1193-1197.

35. Leitz, Ch (ed.). Lexikon der ägyptischen Götter und Götterbezeichnungen, 8 vols., Leuven 2002-2003.

36. Mammisi Dendera: Daumas, F, Les mammisis de Dendara, Cairo, (1959).

37. -Minas, M., Die hieroglyphischen Ahnenreihen der ptolemäischen Könige, Aegyptiaca Treverensia 9, Mainz, (2000).

38. -Murnane, W. J., Ancient Egyptian Coregencies, SAOC 40, Chicago, (1977).

39. Pätznick, P. W., Le lait dans l'Égypte ancienne: entre divin et quotidien. Aux sources d'un élixir de jouvence, in: Arnette, Marie-Lys (ed.), Religion et alimentation en Égypte et Orient anciens 1, RAPH 43, Cairo (2019) 173-198

40. Pestman, P. W., Chronologie égyptienne d'après les textes démotiques (332 av. J.-C. 453 ap. J.-C.), PLB XV, Leiden, (1967).

41. -Poo, M.-Ch., Liquids in Temple Rituals, 2010 (online pdf visited on 29 May 2020: https://escholarship.org/content/qt7gh1n151/qt7gh1n151.pdf)

42. -Ritner, K., Ptolemy IX (Soter II) at Thebes, (pdf-online-version: https://oi.uchicago.edu/sites/oi.uchicago.edu/files/uploads/shared/docs/ptolemy_soter II at thebes.pdf accessed on April 8. 2020)= Ritner, Kenneth, Ptolemy IX Soter II at Thebes, in P. F. Dorman, B. M. Bryan (éd.), Perspectives on Ptolemaic Thebes, Occasional Proceedings of the Theban Workshop, SAOC 65, (2011), 97-114.

43. Sandri, S., Har-Pa-Chered (Harpokrates), Leuven 2006.

44. Thissen, H.-J., 'Kleopatra', in $L \ddot{A}$ III, cols. 452-454.

45. Töpfer, S., Das Balsamierungsritual eine (Neu-)Edition der Textkomposition Balsamierungsritual (pBoulaq 3, pLouvre 5158, pDurham 1983.11 + pSt. Petersburg 18128), Studien zur spätägyptischen Religion 13, Wiesbaden, (2015).

46. von Beckerath, J., Handbuch der ägyptischen Königsnamen, Mainz, (1999).

47. Wilson, P., A Ptolemaic lexicon: a lexicographical study of the texts in the temple of Edfu, Leuven, (1997).

48. Yasuoka, Y., Untersuchungen zu den Altägyptischen Säulen als Spiegel der Architekturphilosophie der Ägypter, QUIA Bd. II, Hützen, (2016).

- 19 - The Column of Cleopatra III and Ptolemy IX 


\section{THE PLATES AND FIGURES}
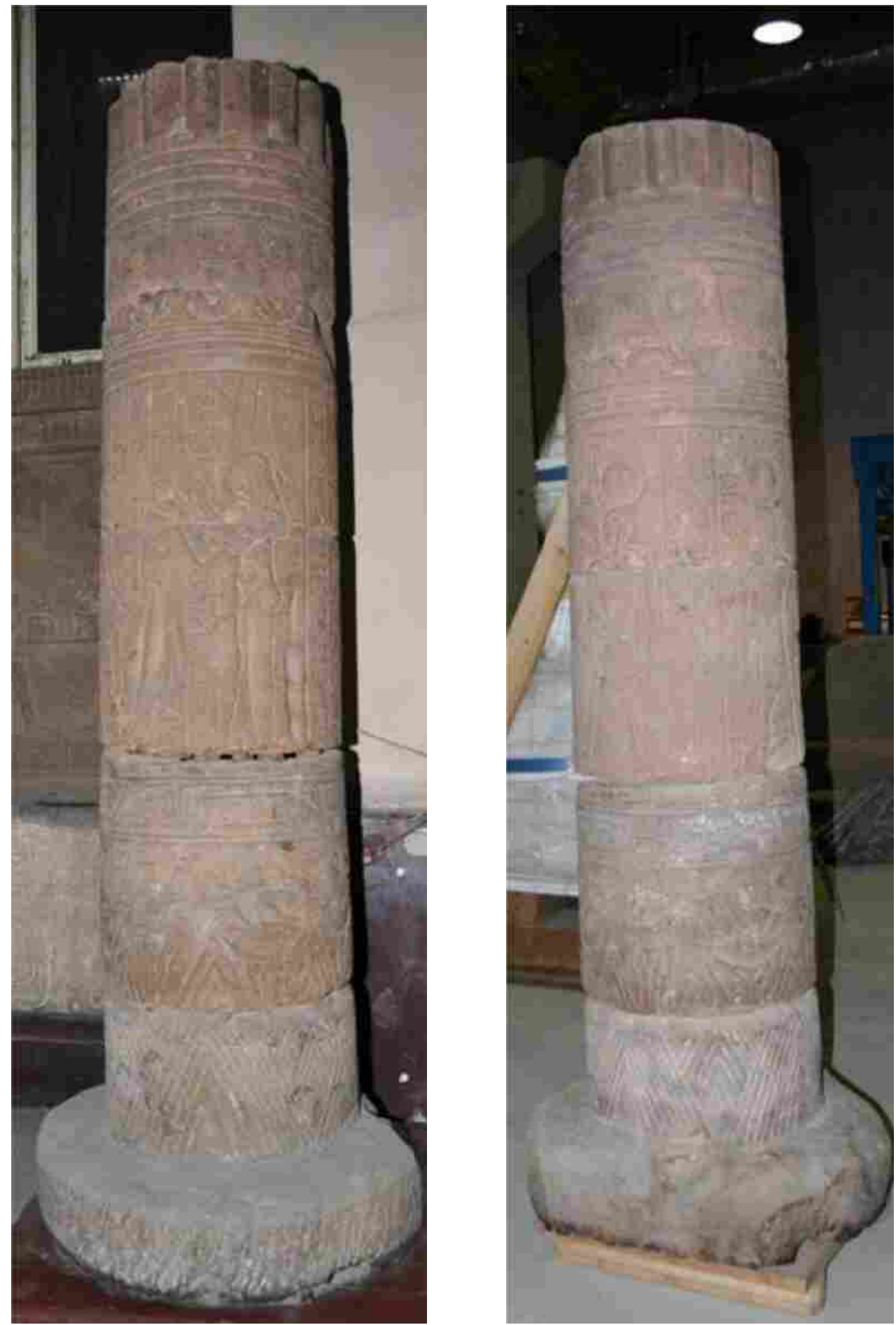

Fig. 1a: Column at the Cairo Museum. b: Column in the laboratory of the GEM. 

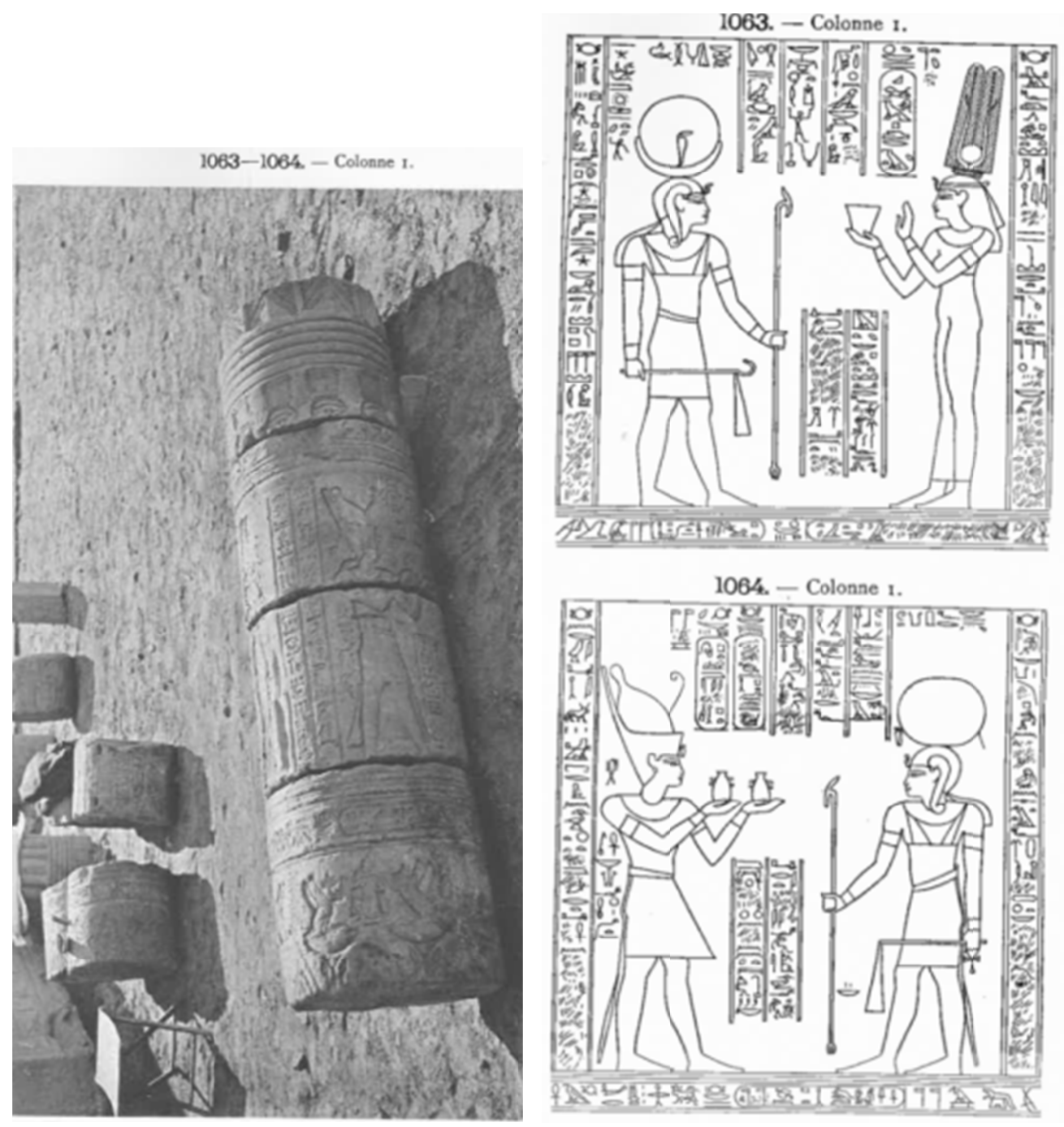

Fig. 2a left: the column's cylindrical block gathered before move to the Cairo Museum in 1914, photo after de Morgan, KO III, p. 345.

Fig. $2 \mathrm{~b}$ right: the main scenes of the column copied by de Morgan showing epigraphic errors. 


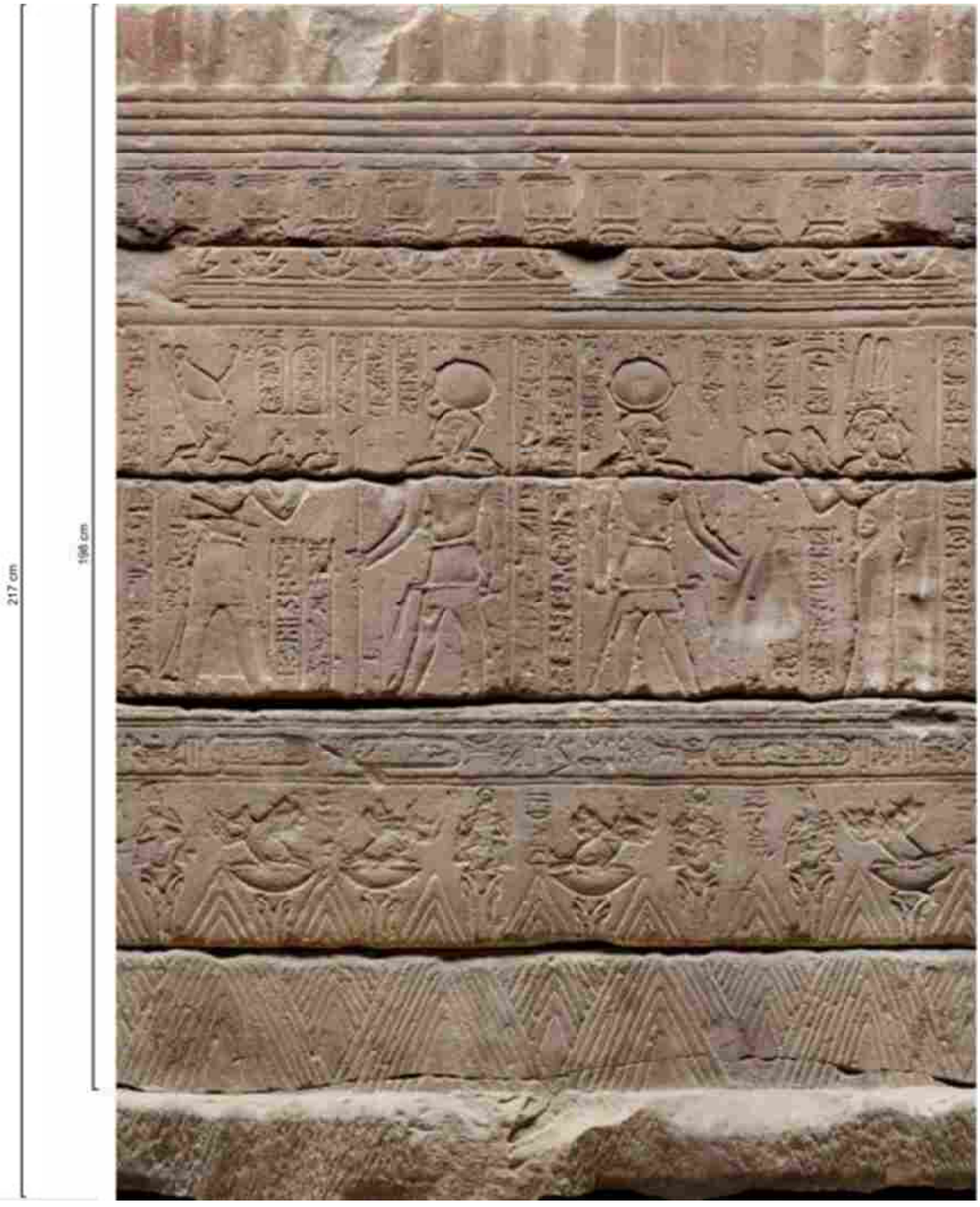

Fig. 3a: Photogrammetry of the column (C) Gael Polin and Ihab Mohammed IFAO. 


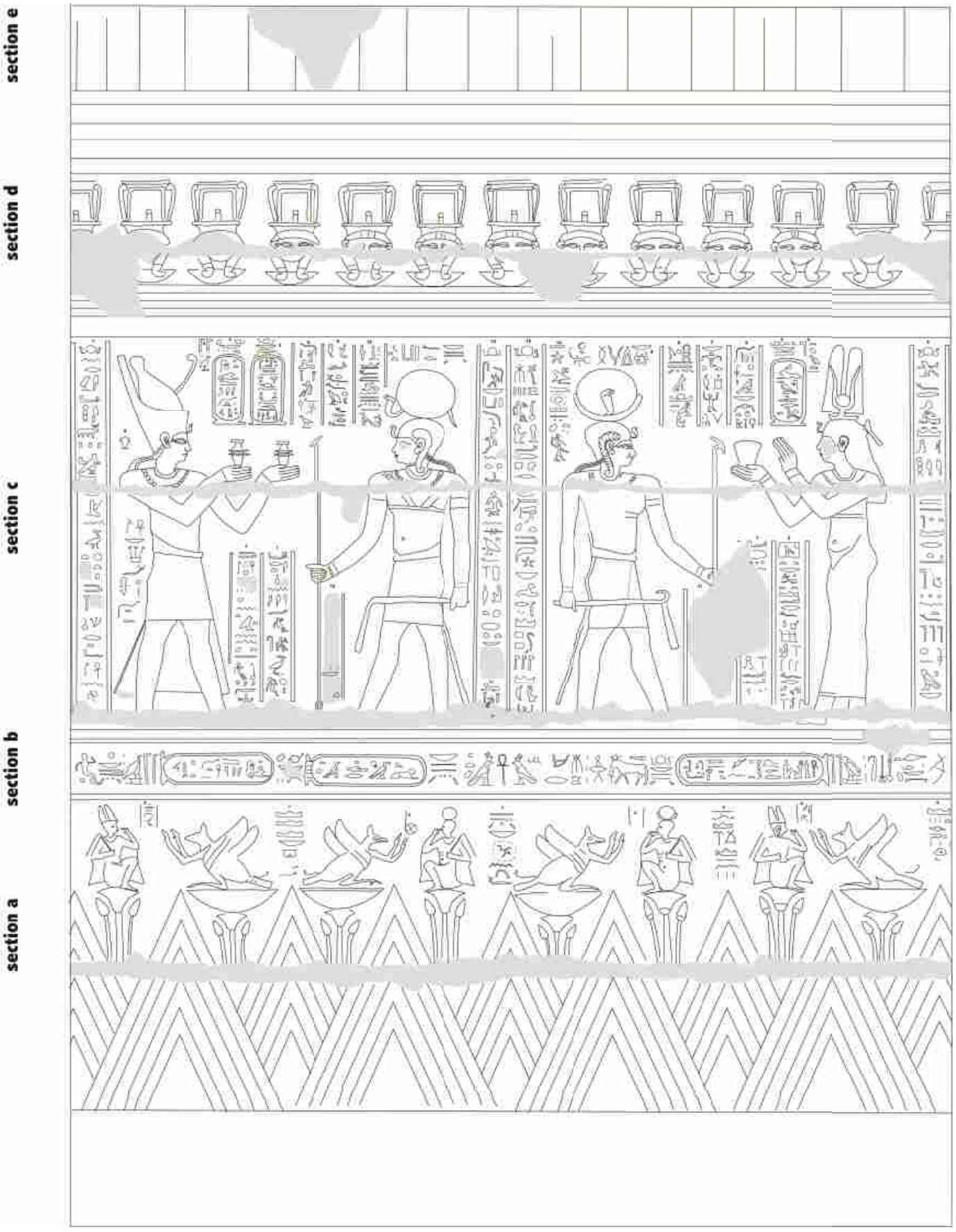

Fig. 3b: Line drawing of the column by the author. 


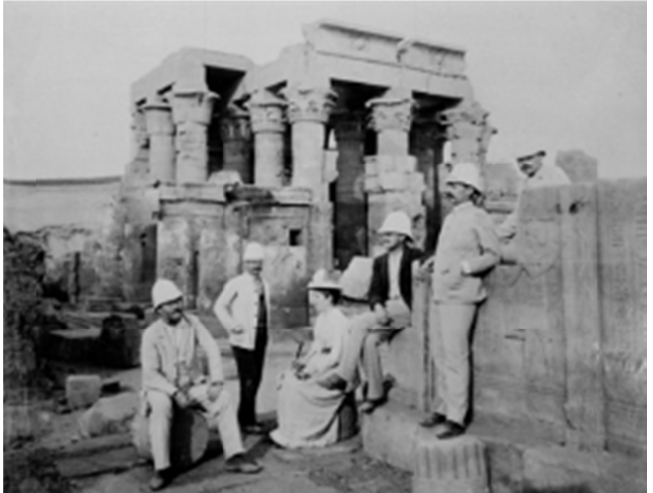

Fig. 4: Cylindrical blocks at the time of discovery behind the screen walls of the mammisi of Kom Ombo. (C) Ifao Archive NB_1975_0586a

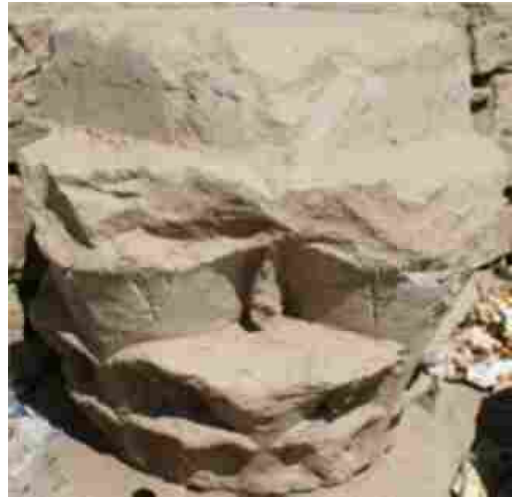

Fig. 5: Capital, matching the column, insitu, in the northern space of the temple complex of Kom Ombo.
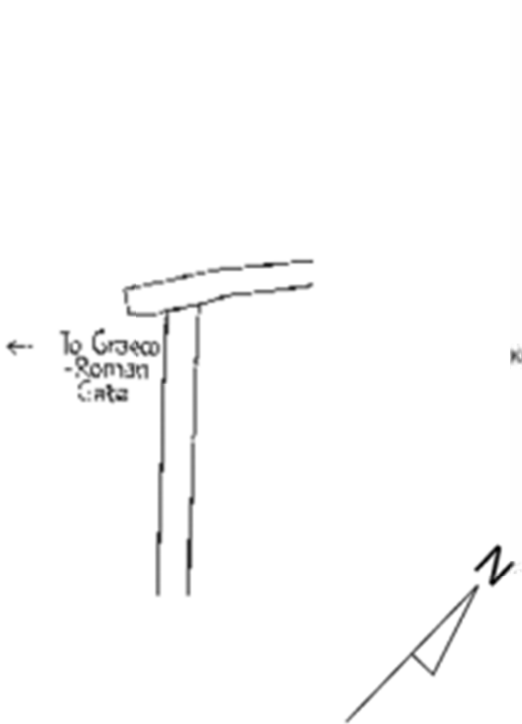

Fig. 6: (reconstructions $\mathrm{b}$ and c plan by the author) a. Old plan of the mammisi after PM

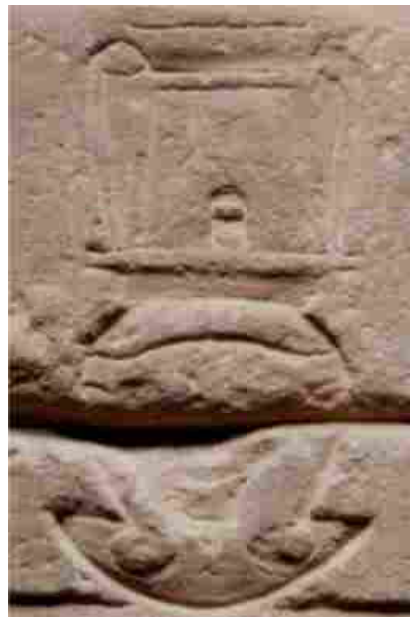

Fig. 7: a.

a-b. Example of decorative frieze of Hathoric faces.

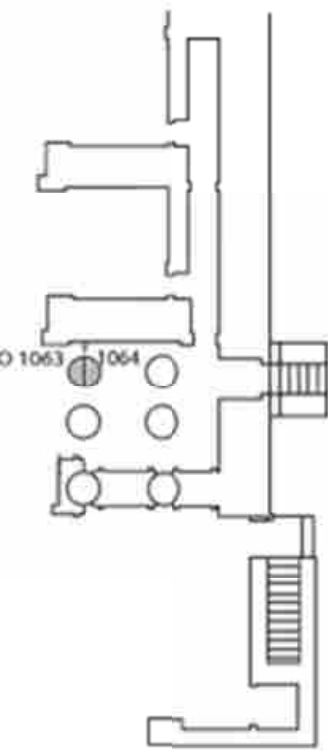

b. Reconstructing the column JE 45072 inside the mammisi of Kom Ombo

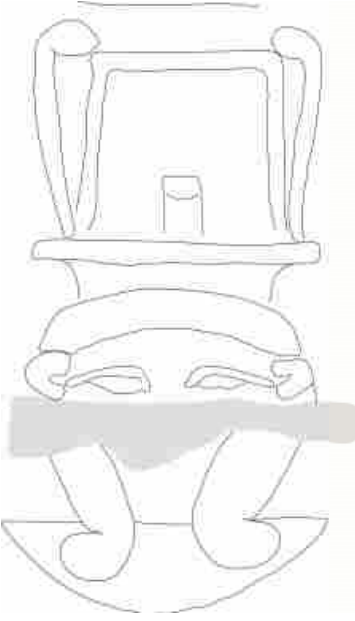

b.

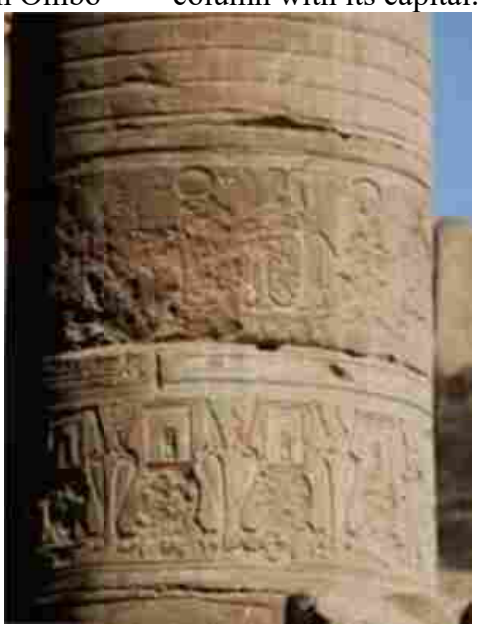

c.

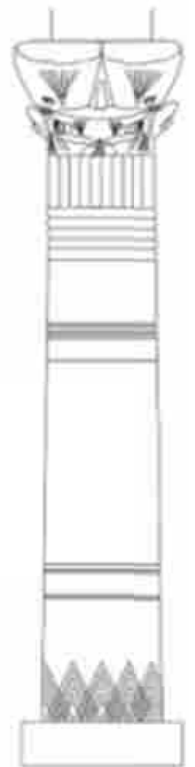

c. Reconstruction of the column with its capital.

c. parallel from the mammisi of Edfu (C) Dagmar Budde). 